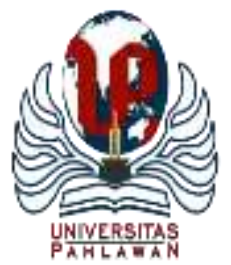

Edukatif : Jurnal Ilmu Pendidikan Volume 3 Nomor 6 Tahun 2021 Halm 4904 - 4912 EDUKATIF: JURNAL ILMU PENDIDIKAN

Research \& Learning in Education

https://edukatif.org/index.php/edukatif/index

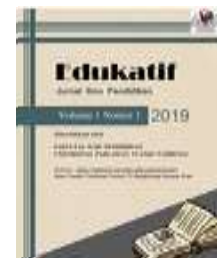

\title{
Teknologi Informasi dan Komunikasi sebagai Salah Satu Pemanfaatan Pembelajaran Pendidikan Kewarganegaraan di Sekolah Dasar
}

\author{
Defany Dwi Rahmadhani ${ }^{1 凶}$, Indah Cahaya Putri², Dinie Anggraeni ${ }^{3}$, \\ Yayang Furi Furnamasari ${ }^{4}$ \\ Universitas Pendidikan Indonesia, Indonesia $1,2,3,4$
}

E-mail : $\underline{\text { defanydwir@upi.edu }}{ }^{1},{\underline{\text { indahcahayap@ } \text { upi.edu }^{2}}}^{\text {,dinieanggraenidwi@ upi.edu }}{ }^{3}, \underline{\text { furi2810 }}$ upi.edu $^{4}$

\begin{abstract}
Abstrak
Saat ini media pembelajaran dirancang sesuai dengan perkembangan teknologi, seperti penggunaan internet, gadget dan alat-alat elektronik pun sudah menjadi menjadi faktor keberhasilan dalam mengembangkan pendidikan, sehingga sudah menjadi keharusan sebagai seorang pendidik untuk mengembangkan media pembelajaran dengan memanfaatkan teknologi informasi dan komunikasi terutama pada Pendidikan Kewarganegaraan sebagai acuan untuk meningkatkan jiwa kebangsaan ditengah perkembangan teknologi di dunia, serta Pendidikan Kewarganegaraan memiliki tujuan tertentu untuk menanamkan nilai-nilai ideologi Pancasila di tengah era globalisasi terhadap generasi muda. Penelitian ini dilakukan untuk menanamkan nilai-nilai ideologi Pancasila di tengah era gloobalisasi terhadap generasi muda, agar generasi muda saat ini tidak terjerumus pada kepada pengaruh negatif dari perkembangan teknologi. Metode penelitian yang digunakan menggunakan metode kualitatif dengan mengumpulkan data dari beberapa Jurnal, Buku Online, dan Karya Ilmiah yang dapat dipercaya karena relevansinya. Pada penelitian ini memiliki peran untuk memfokuskan salah satu cara dalam mencapai tujuan pembelajaran dengan memanfaatkan teknologi komunikasi dan informasi. Karena pada implikasinya pemanfaatan teknologi pada proses pembelajaran ini bisa membuat peserta didik dapat menemukan alternatif dalam belajar, baik itu di sekolah maupun di rumah.
\end{abstract}

Kata Kunci: Media Pembelajaran, TIK, Pembelajaran PKN.

\begin{abstract}
Currently learning media designed in accordance with technological developments, such as the use of the internet, gadgets and electronic devices have become a success factor in developing education, so it has become a necessity as an educator to develop learning media by utilizing information and communication technology, especially in Civic Education as a reference to improve the national spirit amid the development of technology in the world, Citizenship Education has a specific goal to instill the ideological values of Pancasila in the midst of the era of globalization towards the younger generation. This research was conducted to instill the ideological values of Pancasila in the midst of the era of gloobalisasi to the younger generation, so that the current younger generation does not fall into the negative influence of technological development. The research methods used use qualitative methods by collecting data from several Journals, Online Books, and Scientific Works that can be trusted because of their relevance. This research has a role to focus one way in achieving learning goals by utilizing communication and information technology. Because in the implications of the use of technology in this learning process can make learners can find alternatives in learning, both at school and at home.
\end{abstract}

Keywords: Learning Media. TIK, Citizenship Education Learning.

Copyright (c) 2021 Defany Dwi Rahmadhani, Indah Cahaya Putri, Dinie Anggraeni, Yayang Furi Furnamasari

$\triangle$ Corresponding author

Email : defanydwir@upi.edu

DOI : https://doi.org/10.31004/edukatif.v3i6.1574

ISSN 2656-8063 (Media Cetak)

ISSN 2656-8071 (Media Online) 
4905 Teknologi Informasi dan Komunikasi sebagai Salah Satu Pemanfaatan Pembelajaran Pendidikan Kewarganegaraan di Sekolah Dasar - Defany Dwi Rahmadhani, Indah Cahaya Putri, Dinie Anggraeni, Yayang Furi Furnamasari

DOI : https://doi.org/10.31004/edukatif.v3i6.1574

\section{PENDAHULUAN}

Pendidikan merupakan salah satu kunci dari keberhasilan dan kemajuan bagi bangsa. Dengan pendidikan dapat menciptakan metode atau penerapan belajar yang lebih efektif sesuai dengan perkembangan zaman. Proses dan penerapannya pun harus memiliki pembaharuan yang lebih maksimal. Cara agar proses pembelajaran dapat dilakukan dengan maksimal yaitu dengan menciptakan metode pembelajaran yang kreatif. Menurut (Ahyat 2017) mengemukakan metode pembelajaran ialah suau cara atau solusi yang ditempuh dengan sinkron serta serasi dalam mengungkapkan suatu hal sehingga akan tercapai suatu tujuan pembelajaran yang efektif dan efisien sesuai yang diharapkan. Sebagai tenaga pendidik, guru harus bisa mengendalikan keadaan kelas agar suasana kelas dapat lebih menarik dan menyenangkan saat proses belajr mengajar, hal itu perlu dilakukan agar proses pembelajaran dapat lebih bermutu, sehingga yang perlu dilakukan oleh seorang guru adalah membuat metode pembelajaran yang sangatbaik sesuai dengan karakteristik setiap peserta untuk memberikan dampak positif pada siswa.

Untuk membuat metode pembelajaran , maka juga diperlukannya media pembelajaran untuk menunjang keberhasilan tersebut. Media pembelajaran merupakan salah satu faktor eksternal yang menjadi salah satu pengaruh pada meningkatnya prestasi proses belajar siswa. Menurut (Pratiwi, I, T, M., \& Meilani, R 2018) media pembelajaran adalah media atau alat secara fisik yang digunakan pendidik sebagai media untuk memberikan materi pembelajaran seperti buku, gambar, video, proyektor, dll. Dari alat-alat tersebut, peserta didik dapat menciptakan motivasi belajar yang tinggi sehingga strategi belajar tersebut dapat dilakukan dengan baik karena antusias peserta dalam belajar. Karena semakin berkembangnya zaman, metode dan media pembelajaran pun juga mengalami perkembangan. Salah satu metode pembelajaran yang telah dilakukan saat ini yaitu dengan memanfaatkan media teknologi informasi dan komunikasi (TIK), (Darimi 2017).

Upaya memanfaatkan media teknologi informasi dan komunikasi ini untuk menyesuaikan dengan perkembangan dan perubahan yang terjadi di masyarakat karena teknologi di seluruh dunia telah mengalami perkembangan yang sangat pesat yang saling keterkaitan dengan berbagai macam bidang dan salah satunya adalah bidang pendidikan. Bahkan saat ini pendidik dituntut untuk dapat bisa menggunakan teknologi sebagi media pembelajaran yang paling efektif. Hal ini dirasa memiliki peluang yang besar agar peserta didik dapat memiliki keterampilan yang baik dengan teknologi, terutama untuk memperoleh informasi secara cepat dan mudah dengan ruang lingkup yang luas terutama pada bidang pendidikan. Menurut (Japar, M., Fadhillah, D, N., \& Lakshita 2019) karena berkembangnya teknologi yang mempermudah pada dunia pendidikan terutama dalam mengembangkan media pembelajaran, media pembelajaran yang diciptakan sebaiknya mencermati pada setiapkarakteristik siswa yang berkaitan dengan motivasi, bakat, minat, kemampuan awal, gaya belajar, dan kepribadian.

Selain itu, pemanfaatan teknologi pada bidang pendidikan yang salah satunya adalah Pendidikan Kewarganegaraan dapat mendukung para pendidik untuk menyampaikan materi dengan jelas dan terperinci sebab penggunaan teknologi yang digunakan. Selain pendidik, peserta didik juga dapat memperoleh informasi mengenai Pendidikan Kewarganegaraan tanpa adanya batas waktu dan ruang. Saat ini, salah satu teknologi yang digunakan peserta didik adalah smartphones. Dengan begitu, peserta didik dapat belajar secara mandiri dengan menggunakan smartphones. Sehingga para pendidik pun harus lebih berupaya untuk memperharui bahan ajar yang lebih luas terutama pada Pendidikan Kewarganegaraan. Namun, beberapa kendala saat proses pembelajaran pun bisa terjadi kapan saja, walaupun pendidik telah melakukan suatu upaya untuk meningkatkan pengembangan belajar siswa melalui media pembelajaran yang kreatif dan berkembang, tetapi tetap saja ada hambatan-hambatan yang dapat terjadi ketika menggunakanakan media pembelajaran dengan memanfaatkan teknologi. Maka, pada penelitian ini dilakukan untuk mencari tahu dimana letak hambatan tersebut serta menemukan solusi pada hambatan tersebut. 
4906 Teknologi Informasi dan Komunikasi sebagai Salah Satu Pemanfaatan Pembelajaran Pendidikan Kewarganegaraan di Sekolah Dasar - Defany Dwi Rahmadhani, Indah Cahaya Putri, Dinie Anggraeni, Yayang Furi Furnamasari

DOI : https://doi.org/10.31004/edukatif.v3i6.1574

\section{METODE PENELITIAN}

Penelitian ini bertujuan untuk menganalisis pengaruh teknologi dan komunikasi dalam media pembelajaran di sekolah, khususnya dalam mata pelajaran kewarganegaraan, ada beberapa literatur yang dikaji dalam penulisan artikel ini alasan pemilihan sumber literatur yang kami pilih dikarenakan sebagai penguat paparan penilitian yang kami buat. Ini dilakukan dengan menggunakan metode kualitatif dan pendekatan studi pustaka berdasarkan dari penelitian literatur, dengan cara mengumpulkan dari berbagai jenis jurnal yangsudah dietrbitkan yang berakreditasi gogglescholar, juga artikel, tesis, dan buku online (Pertiwi, W. H. S., \& Weganofa 2015). Metode ini dapat memuat uraian data berupa sebuah penulisan orang-orang yang diamati padapenelitian yang sebelumnya telah dilakukan.

Pada metode kualitatif ini, penelitian ini lebih menegaskan dengan menganalisis terhadap sumbersumber kepustakaan yang telah dikumpulkan, data pada penelitian lain yang sebelumnya pernah dilakukan, teori dan definisi sesuai dengan topik penelitian,dan lain-lain yang dapat diarahkan pada tujuan utama penelitian,dengan tahapan mengerucutkan sejumlah data,penyajian data,dan kesimpulan sesuai dengan penguat jurnal atau sumber yang telah kami cantumkan.

\section{HASIL DAN PEMBAHASAN PENELITIAN}

\section{Memanfaatkan TIK Sebagai Media Pembelajaran di Sekolah}

Macam-macam jenis teknologi informasi dan komunikasi itu sangatlah banyak. Menurut (Sejati, N, D, R 2011), mengatakan bahwa ada tiga macam ruang lingkup kegiatan dalam pemanfaatan teknologi informasi dan komunikasi, yaitu; a) menggunakan teknologi informasi dan komunikasi sebagai media alat bantu saat proses pembelajaran, b) pengorganisiran atau menyusun data-data dan informasi sekolah menggunakan teknologi, c) menggunakan teknologi informasi dan komunikasi sebagai layanan pendidikan yang dapat digunakan oleh masyarakat dengan fleksibel.

Tetapi yang banyak dimanfaatkan pada dunia pendidikan masih terbatas, biasanya yang tersedia pada sekolah yaitu, personal computer, televisi, radio, proyektor, dan internet. Personal computer serta proyektor adalah suatu media rancangan yang mana pada pemanfaatannya sangat diperlukan perancangan khusus serta dirancang sedemikian rupa supaya dapat dimanfaatkan dengan baik. Komputer mempunyai fungsi buat menyimpan bahan pelajaran yang bisa dimanfaatkan kapan saja diharapkan. Fungsi personal komputer terus berkembang termasuk berbagai fasilitas yang ada pada dalamnya. Selain personal komputer, media berbasis teknologi informasi dan komunikasi lainnya itu yaitu menggunakan proyektor. Penggunaan proyektor pada pembelajaran ini ialah sistem penyimpanan materi yang sengaja dibuat oleh pengajar buat mempermudah pada penyampaian bahan ajar, sebab proyektor mempunyai kemampuan buat memanipulasi ruang dan waktu.

Pemanfaatan proyektor pembelajaran sangat mudah serta praktis, hanya langsung diputar dan dihubungkan menggunakan laptop. Asal segi kemudahan media ini dipandang praktis buat digunakan, proyektor hanya tinggal diputar dengan laptop. (De Porter, B, \& Hernacki. M 2000) dengan memanfaatkan proyektor pembelajaran sebagai media pembelajaran merupakan pengajar mata pelajaran bahasa serta guru mata pelajaran hayati dikarenakan proyektor pembelajaran buat mata pelajaran tersebut diperjualbelikan sebagai akibatnya mudah pada pemanfaatannya ataupun guru bisa membuat sendiri. Untuk menghailkan prmbr;ajaran dengan menggunakan proyektor diperlukan kompetensi pengajar yang cukup mahir dan terbiasa membuatnya, sinkrondengan pendapat pengajar Pendidikan Kewarganegaraan yang mengatakan bahwa untuk menghasilkan proyektor pembelajaran akan tetapi kurang berhasil dalam pemanfaatannya, maka pembelajaran hasilnya akan kurang cocok dengan yang dibutuhkan, sehingga dapat menggangu aktivitas proses pembelajaran. 
4907 Teknologi Informasi dan Komunikasi sebagai Salah Satu Pemanfaatan Pembelajaran Pendidikan Kewarganegaraan di Sekolah Dasar - Defany Dwi Rahmadhani, Indah Cahaya Putri, Dinie Anggraeni, Yayang Furi Furnamasari

DOI : https://doi.org/10.31004/edukatif.v3i6.1574

Proyektor pembelajaran mempunyai kekurangan yaitu rentan rusak, membutuhkan waktu yang cukup lama untuk membuat video atau pun presentasi, serta bila peserta didik belajar sendiri di rumah dengan menonton video tersebut dan terdapat materi yang tidak diketahui, peserta didik tidak bisa bertanya langsung kepada pengajar. Televisi adalah media pengajaran yang bisa disajikan di ruang kelas dan dapat menyajikan acara atau program yang dapat dipahami pada strata pendidikan, tetapi televisi hanya menyajikan komunikasi satu arah dan tidak bisa menjangkau kelas besar sehingga dikhawatirkan peserta didik bersifat pasif selama penayangan. Sebagai sumber belajar yang akibatnya pengajar tidak mampu mengawasi peserta didik ketika di rumah. Televisi merupakan salah satu sumber belajar yang penting ketika berada di luar sekolah, sehingga siswa mampu permanen belajar dengan orang tua masing-masing yang bisa membimbing anaknya.

Peran orang tua peran orang tua sangat krusial waktu siswa telah berada di luar sekolah, masingmasing orang tua peserta didik harus pandai - pandai memilih acara di televisi yang sesuai buat anak-anak mereka.sinkron dengan pendapat. Media televisi hanya di gunakan untuk sumber belajar peserta didik pada rumah serta guru juga tidak bisa memantau, itu tergantung masng-masing individu serta peran orang tua.radio artinya indera elektronik yang muncul daru yang akan terjadi teknologi komunikasi. Memalui indera ini orang dapat mendengarkan siaran berasal banyak sekali penjuru dan peristiwa. (Fraenkel, R.J, \& Wallen 1990) di radio pendidikan, umumnya siaran spesifik buat pendidikan di atur menggunakan jadwal, oleh karena itu susah untuk menyesuaikan jadwal pelajaran sekolah. Radio juga sama halnya dengan televisi, hanya saja menjadi asal belajar sisa jadi pengajar tidak bisa mengawasi secara langsung bahwa sumber belajar itu di gunakan atau tidak.sekarang pemanfaatnya dengan media yang terkini seperti internet, maka pemanfaatan radio di fokuskan hanya sebagai asal belajar peserta didik waktu di luar saja. Internet adalah sebuat jaringan komputer global, yang terdiri asal jutaan personal komputer yang saling terhubung dengan menggunakan protokol yang sama buat aneka macam berita secara bersama, (Nurgiansyah, T 2021).

Komputer dengan koneksi internet sudah tersedia di sekolah ini seperti komputer yang ada di ruang perpustakaan dan ruang laboratorium. Sekolah ini juga sudah memiliki fasilitas hotspot. Baik guru ataupun siswa bisa menggunakan fasilitas internet tersebut tanpa harus keluar dari lingkungan sekolah. Di luar sekolah juga sudah banyak menyediakan warung-warung internet yang bisa dimanfaatkan oleh siswa ataupun guru. Hal ini sesuai dengan pendapat guru PKn (pada tanggal 01 Juni 2011) yang menyatakan bahwa: "saya memanfaatkan fasilitas internet yang ada di sekolah untuk menambah bahan materi pelajaran. Jadi saya tidak perlu keluar sekolah untuk mencari informasi lewat internet. Dikarenakan sekarang itu jamannya sudah modern makanya di dalam sekolah sudah tersedia fasilitas hotspot".

Dalam konteks pendidikan yang lebih umum, teknologi pendidikan merupakan pengembangan, penerapan, dan penilaiansistem teknik dan alat bantu untuk memperbaiki dan meningkatkan kualitas belajar manusia, dengan demikian aspek - aspeknya meliputi pertimbangan teoritik yang merupakan hasil hasil penelitian, perangkat dan peralatan teknis atau hardware dan perangkat lunak software, aspek - aspek tersebut difungsikan untuk mendesign, melaksanakan penilaian pendidikan dengan pendekatan yang sistematis. Dalam wacana yang berkembang selama ini ada dua istilah yang perlu dibedakan, yakni kewargaannegara dan kewarganegaraan. Istilah kewargaannegara merupakan terjemahan dari "Civics" yang merupakan mata pelajaran sosial yang bertujuan membina dan mengembangkan anak didik agar menjadi warga negara yang baik (good citizen). "Warga negara yang baik adalah warga negara yang tahu, mau dan mampu berbuat baik" dalam modul.

Personal komputer menggunakan koneksi internet telah tersedia pada sekolah ini mirip komputer yang terdapat pada ruang perpustakaan dan ruang laboratorium beberapa sekolah juga sudah memiliki fasilitas hospot baik guru ataupun peserta didik yang dapat memakai fasilitas internet tersebut tanpa harus keluar dari lingkungan sekolah. Di luar sekolah pula sudah lingkungan yang menyediakan warung warung internet yang bisa di manfaatkan oleh peserta didik maupun pengajar. Pada konteks pendidikan yang lebih umum, teknologi 
4908 Teknologi Informasi dan Komunikasi sebagai Salah Satu Pemanfaatan Pembelajaran Pendidikan Kewarganegaraan di Sekolah Dasar - Defany Dwi Rahmadhani, Indah Cahaya Putri, Dinie Anggraeni, Yayang Furi Furnamasari

DOI : $\quad$ https://doi.org/10.31004/edukatif.v3i6.1574

pendidikan adalah pengembangan, penerapan serta penilaian sistem teknik dan indra bantu buat memperbaiki dan meningkatkan kualitas belajar insan, dengan demikian komponen komponnya meliputi pertimbangan teoritik yang merupakan akan terjadi penelitan, perangkat serta peralatan teknis atau hardware dan software aplikasi,komponen komponen tadi di gunakan untuk menggambarkan, melaksanakan penilaian menggunakan pendekatan yang tersruktur. Dalam prihal yang berkembang selama ini terdapat dua kata yang perlu di bedakan, yaitu kewarganegara dan kewarganegaraan.

Istilah kewarganegaraan adalah terjamahan dari "Civic" yang merupakan mata pelajaran sosial yang bertujuan untuk memimpin serta mengutaran kepada peseta didik supaya dapat menjadi rakyat negara yang baik. Kata kewarganegaraan di gunakan pada perundang undangan tentang status formal rakyat negara dalam suatu negara, namun ada dua konsep tersebut kini di pergunakan sercara konseptual di adopsi asal kata citizenship,(Hidayat, H., Mulyani, H., Nurhasanah, S. D., Khairunnisa, W., \& Sholihah 2020)Secara umum di artikan menjadi hal hal yang terkait di status aturan serta karakter masyarakat negara, sebagai mana di gunakan pada perundang undangan kewarganegaraan buat status hukum masyarakat negara, dan pendidikan kewarganegaraan untuk acara pengembangan karakter rakyat negara secara kulikuler. Istilah model pembelajaran sangat dekat dengan taktik pembelajaran dari beberapa pakar mendefinisikan taktik,metode,pendekatan dan teknik pembelajran, yaitu:

1) Taktik pembelajaran merupakan seperangkat kebijaksanakaan yang terpilih yang dihubungkan denganfaktor faktor yang menentukan warna langkah langkah tersebut di antaranya materi pelajaran materi bahan ajar, cara penyampaian, dan sasaran kepada peserta didik.

2) Pendejatan pembelajaran artinya proses yang di tempuh para pendidik atau peserta didik dalam mencapai tujuan pembelajaran pada cara menyajikannya.

3) Metode pembelajaran merupakan suatu cara mengajar secara umum yang bisa di terapkan di seluruh mata pelajran, contohnya dengan menggunakan teknik ceramah,tanya jawab atau penemuan terbimbing.

4) Metode mengajar adalah suatu penerapan yang secara khusus yang sudah di sesuaikan dengan kemampuan dan kebiasan guru pada kesiapan edia pembelajaran dan peseta didik, (Nurdyansyah, N., \& Fahyuni 2016).

Pembelajaran dengan memakai teknologi berlaku pada kemandirian peserta didik dalam belajar. Hal tersebut di tampikan pada aktifitas peserta didik selama proses belajar mengajar dan terbukti menggunakan meningkatnya pemahaman pesrta didik yang di cermati berasal akibat belajar peserta didik. Pembeljaran memakai teknologi multimedia klasikal tak berperan dalam menciptakan kemandirian pesrta didik saat belajar akan tetapi peranan tersebut jelas dapat membantu, bila kegiatan tersebut bisa dipelajari mandiri di luar jam pelajaran, sebab di kaitkan dengan beberpa teori belajar untuk meningkatkan motifasi mencari informasi yang di dapatkan setelah proses belajar di lakukan. Hal tesebut serupa dengan yang di perlukan dapat mengembangkan kualitas pendidikan (Darimi 2017). Di terangkan pula bahwa pembelajaran yang baik merupakan pembelajaran yang mampu mempengaruhi belajar peserta didik yang dilihat dari faktor dalam diri peserta didik maupun faktor dari luar peserta didik. Serta dapat di tentukan pula faktor pendekatan belajar yang dapat di terapkan.

\section{Pemanfaatan Media Berbasis TIK pada Pendidikan Kewarganegaraan}

Penggunaan sarana pembelajaran berbasis TIK dalam proses belajar mengajar dapat membangkitkan keinginan dan minat baru dalam inovasi pembelajaran, membangkitkan motivasi dan merangsang kegiatan belajar. Penggunaan alat peraga akan sangat membantu efektifitas proses pembelajaran dan penyampaian pesan dan isi pelajaran. Selain itu juga dapat meningkatkan pemahaman, menyajikan data secara menarik dan terpercaya, memudahkan interpretasi data, dan memadatkan informasi. Tujuan pendidikan kewarganegaraan 
4909 Teknologi Informasi dan Komunikasi sebagai Salah Satu Pemanfaatan Pembelajaran Pendidikan Kewarganegaraan di Sekolah Dasar - Defany Dwi Rahmadhani, Indah Cahaya Putri, Dinie Anggraeni, Yayang Furi Furnamasari

DOI : https://doi.org/10.31004/edukatif.v3i6.1574

pada dasarnya adalah menjadikan warga negara yang cerdas dan baik serta mampu mendukung keberlangsungan bangsa dan negara. Mata pelajaran Pendidikan Kewarganegaraan lebih fungsional bagi peserta didik dengan mendekatkan mereka pada lingkungan atau kehidupan sehari-hari (sosial, ekonomi, politik, dan sebagainya) baik lokal maupun internasional.

Pemanfaatan media pembelajaran berbasis TIK pada mata pelajaran PKn sebagai sarana untuk mempermudah penyampaian materi bagi guru dengan menggunakan teknologi informasi dan komunikasi yang berkembang pesat, seperti komputer dengan jaringan internet, komputer dan LCD proyektor. Penggunaan media pembelajaran kewarganegaraan menjadi lebih menyenangkan dan bervariasi, serta meningkatkan minat siswa dalam memahami materi yang disampaikan oleh guru. Guru dapat membuat media sendiri untuk digunakan sebagai alat bantu dalam proses belajar mengajar (Lestari, I., \& Pratama, M 2020)Media yang digunakan sebagai alatbantu dapat menjadi motor penggerak bagi siswa dan mempermudah pemahaman materi yang disampaikan oleh guru.

Menurut Hamalik dalam (Arsyad 2004), penggunaan media pembelajaran dalam proses belajar mengajar dapat membangkitkan keinginan dan minat baru, membangkitkan motivasi dan rangsangan kegiatan belajar bahkan menimbulkan efek psikologis bagi siswa. Media pembelajaran merupakan sarana bagi guru untuk membuat proses belajar mengajar lebih menyenangkan dan tidak membosankan serta dapat meningkatkan motivasi belajar. Media pembelajaran berbasis teknologi informasi dan komunikasi menarik perhatian siswa pada topik. Animasi bergerak, penuh warna, mencari informasi di Internet yang dapat disediakan oleh media berbasis ICT.

Keunggulan media pembelajaran dalam proses belajar siswa, yaitu:

a) pembelajaran akan menarik perhatian siswa sehingga dapat meningkatkan motivasi belajar,

b) didaktis materi lebih jelas maknanya sehingga lebih dipahami oleh siswa dan memungkinkan mereka menguasai dan mencapaitujuan pembelajaran,

c) metode pengajaran menjadi lebih beragam, bukan hanya komunikasi verbal melalui narasi guru sehingga Siswa tidak bosan dan guru tidak kehabisan tenaga apalagi jika mengajar semua pelajaran di aekolah.

d) Siswa dapat melakukan kegiatan belajar lebih banyak karena tidak hanya mendengarkan penjelasan guru tetapi juga kegiatan lain seperti melihat, melakukan, mendemonstrasikan, bertindak, dan lain-lain.

Hal ini dikarenakan ketika guru menggunakan media berbasis TIK sebagai sarana pembelajaran, hal. Misalnya simbol atau gambar dalam gerakan dan dengan demikian menarik perhatian siswa (Ariani, N., \& Haryanto 2010). Menggunakan power point dengan animasi yang menarik perhatian siswa dapat mengurangi kebosanan siswa dengan topik yang cenderung dihafal. Anda juga dapat menyegarkan pikiran siswa dengan menggunakan media agar pikiran siswa tidak tertekan oleh pelajaran PKn.

Internet dapat meningkatkan motivasi belajar dan menambah pengetahuan siswa tentang topik selain buku. Penggunaan media internet sebagai sarana pembelajaran dapat memberikan kesempatan kepada siswa untuk mencari informasi tentang mata pelajaran, (Anshori 2018). Koneksi internet yang sangat luas memberikan siswa gambaran yang komprehensif, karena sumber belajar siswa tidak terobsesi dengan buku. Internet sebagai sarana pembelajaran memiliki kelebihan, antara lain: a) Internet menawarkan koneksi (konektivitas) dan cakupan tak terbatas yang sangat luas. b) Akses informasi di internet tidak dibatasi waktu, karena dunia maya yang dihadirkan secara global tidak pernah tidur. c) Mengakses informasi di internet lebih cepat daripada mencari informasi di halaman buku perpustakaan. d) Internet juga menawarkan kegiatan pembelajaran interaktif seperti fasilitas e-learning yang diselenggarakan oleh institusi tertentu yang dapat meningkatkan kemampuan intelektual kita seperti sekolah menulis online dll. e) Anda dapat mendiskusikan 
4910 Teknologi Informasi dan Komunikasi sebagai Salah Satu Pemanfaatan Pembelajaran Pendidikan Kewarganegaraan di Sekolah Dasar - Defany Dwi Rahmadhani, Indah Cahaya Putri, Dinie Anggraeni, Yayang Furi Furnamasari

DOI : https://doi.org/10.31004/edukatif.v3i6.1574

hal-hal yang berbeda saat mengobrol dengan rekan-rekan Anda atau pada pijakan yang sama. f) Jauh lebih murah untuk mencari informasi di Internet daripada membeli buku atau majalah asli.

Penggunaan media berbasis TIK sebagai sarana pembelajaran dapat mengoptimalkan kerja otak siswa. Animasi, gambar dan warna dapat mengaktifkan belahan otak kanan siswa saat mencari ide, mengungkapkan ide, menentukan kata kunci, belahan kiri bekerja. Jadi ketika guru menggunakan media sebagai sarana pembelajaran, kedua sisi otak siswa berfungsi. Kerja dua otak siswa membuat siswa lebih cepat mengingat informasi yang diterimanya, sehingga siswa merasa senang dan juga tidak tertekan saat belajar (Harha 2014). Emosi siswa selama belajar menjadi tenang dan stabil, sehingga siswa tidak bosan atau bersemangat saat belajar berikutnya. Ketika siswa belajar, tidak hanya IQ, tetapi juga emosi yang terlibat, sehingga mereka dapat memandu keputusan siswa setiap saat. Hal ini sejalan dengan pendapat Daniel Goleman yang mengatakan bahwa kehidupan dan pembelajaran seseorang tidak hanya melibatkan IQ tetapi juga emosi, suasana dan pikiran (emotional power) (De Porter, B, \& Hernacki. M 2000).

Pembelajaran yang melibatkan emosi, perasaan, dan keterampilan pribadi sangat berpengaruh dan bertahan lama. Media pembelajaran adalah cara yang bagus untuk menghasilkan respons emosional seperti rasa takut, takut, empati, cinta, dan kegembiraan. Bahan ajar menjadi lebih jelas Hasil penelitian menunjukkan bahwa bahan ajar menjadi lebih jelas melalui penggunaan alat peraga dalam kegiatan belajar mengajar. Bahan ajar menjadi lebih detail dan mudah dipahami siswa. Menurut (Anjani 2016) media pembelajaran sebagai alat pembelajaran yang berfungsi untuk mentransmisikan konten dengan cara yang lebih variatif, menghibur dan tidak membosankan, sehingga siswa lebih aktif dalam proses belajar mengajar. Media pembelajaran dapat membuat hal-hal yang abstrak menjadi lebih konkrit. 3. Metode pengajaran semakin bervariasi Penggunaan media membuat metode pengajaran semakin beragam dan tidak membuat siswa bosan mengikuti proses belajar mengajar dan lebih menyenangkan (Prasetyo, Y 2018).

Media pembelajaran memiliki beberapa nilai praktis, antara lain: 1) media pembelajaran dapat mengatasi perbedaan pengalaman siswa 2) media pembelajaran dapat membangkitkan semangat dan motivasi baru untuk belajar serta merangsang keaktifan siswa dalam belajar 3) media pembelajaran dapat mempengaruhi abstraksi 4) media pembelajaran dapat memperkenalkan, meningkatkan, memperluas dan memperjelas pemahaman konsep dan fakta 5) media dapat membantu melampaui batas-batas indera manusia 6) Media dapat mengatasi keterbatasan ruang dan waktu 7) Media dapat belajar benda-benda yang berupa benda-benda langka atau kejadian-kejadian yang ada dan masuk ke dalam kelas secara berbahaya. Kemudian siswa dapat melakukan lebih banyak kegiatan dan siswa dapat berpartisipasi lebih aktif dalam proses belajar mengajar.

Melalui penggunaan media pembelajaran memungkinkan siswa untuk melakukan lebih banyak kegiatan belajar seperti mengamati, bertindak, mendemonstrasikan dan bertindak. Media pembelajaran adalah segala sesuatu yang dapat digunakan untuk menyampaikan informasi dari guru kepada siswa sehingga dapat merangsang pikiran, perasaan, perhatian, dan minat siswa dan pada akhirnya mengarahkan siswa pada kegiatan belajar.

\section{SIMPULAN}

Teknologi digital menjadi salah satu kebutuhan pendidikan pada zaman sekarang ini terutama dalam mata pelajaran PKn karena proses pembelajaran PKn di maknai sebagai wahana pembelajaran atau bentukan jati diri dan cinta terhadap tanah air melalui internalisasi atau personalisasi nilai agama dan budaya yang melandasi nilai-nilai kemanusiaan, nilai politik, nilai ilmu pendidikan dan teknologi, nilai seni, nilai ekonomi, dan nilai kesehatan yang merupakan kegiatan dasar manusia dala rangka membangun wawasan warga negara menjadi lebih baik. Itu lah mengapa begitu sangat pentingnya pembelajaran PKn bagi siswa untuk 
4911 Teknologi Informasi dan Komunikasi sebagai Salah Satu Pemanfaatan Pembelajaran Pendidikan Kewarganegaraan di Sekolah Dasar - Defany Dwi Rahmadhani, Indah Cahaya Putri, Dinie Anggraeni, Yayang Furi Furnamasari

DOI : https://doi.org/10.31004/edukatif.v3i6.1574

menumbuhkan rasa cinta tanah air, tetapi beberapa hasil penelitian yang menunjukan pembelajaran PKn yang selama ini kurang efektif yang biasanya menggunakan metode ceramah di sinilah pean teknologi yang menjadi solusi dari masalah tersebut yang mana salah satunya adalah gambar, power point, vidio dan lain-lain.

\section{UCAPAN TERIMA KASIH}

Jika perlu berterima kasih kepada pihak tertentu, misalnya sponsor penelitian, nyatakan dengan jelas dan singkat, hindari pernyataan terima kasih yang berbunga-bunga.

\section{DAFTAR PUSTAKA}

Ahyat, N. 2017. "Metode Pembelajaran Pendidikan Agama Islam." Edusiana: Jurnal Manajemen Dan Pendidikan Islam 4(1):24-31.

Anjani, C. K. 2016. "Peningkatan Presefsi Belajar Pkn Melalui Video Pada Kelas Iv Sd Negeri Sleman 5." Jurnal Pendidikan Guru Sekolah Dasar Edisi 23.

Anshori, S. 2018. "Pemanfaatan Teknologi Informasi Dan Komunikasi Sebagai Media Pembelajaran.” CivicCulture:Jurnal Ilmu Pendidikan Pkn Dan Sosial Budaya.

Ariani, N., \& Haryanto, D. 2010. "Pembelajaran Multimedia Di Sekolah.” In Jakarta: Prestasi Pustaka.

Arsyad, N. 2004. “Media Pembelajaran.” In Jakarta: Pt Grafindo Persada.

Darimi, I. 2017. "Teknologi Informasi Dan Komunikasi Sebagai Media Pembelajaran Pendidikan Agama Islam Efektif." Jurnal Pendidikan Teknologi Informasi 1(2):111-21.

Fraenkel, R.J, \& Wallen, N. C. 1990. "How To Design And Evaluate Research In Education.” In London: Mc Graw Hill, Inc.

Harha, K. 2014. "Peningkatan Minat Belajar Siswa Dalam Pembelajaran Pkn Dengan Menggunakan Media Gambar Pada Siswa Kelas Iv Sdn 26 Bukit Tambun Tulang Kabupaten Pesisir Selatan. , 2(1)." Abstract Of Undergraduate, Faculty Of Education, Bung Hatta University 2(1).

Hidayat, H., Mulyani, H., Nurhasanah, S. D., Khairunnisa, W., \& Sholihah, Z. 2020. "Peranan Teknologi Dan Media Pembelajaran Bagi Siswa Sekolah Dasar Di Dalam Pembelajaran Pendidikan Kewarganegaraan." Jurnal Pendidikan Kewarganegaraan Undiksha 8(2):57-65.

Japar, M., Fadhillah, D, N., \& Lakshita, G. 2019. "Media Dan Teknologi Pembelajaran Pkn.” In Surabaya: Cv. Jakad Publishing Surabaya.

Lestari, I., \& Pratama, M, H. 2020. "Pemanfaatan Tik Sebagai Media Pembelajaran Dan Sumber Belajar Oleh Guru Tik." Jurnal Pendidikan Informatika. 4(2):95-102.

Nurdyansyah, N., \& Fahyuni, E. F. 2016. "Inovasi Model Pembelajaran Sesuai Kurikulum 2013.”

Nurgiansyah, T, H. 2021. "Pemanfaatan E-Learning Dalam Pembelajaran Pendidikan Kewarganegaraan." Jintech: Journal Of Information Technology. 2(2):138-46.

Pertiwi, W. H. S., \& Weganofa, R. 2015. "Pemahaman Mahasiswa Atas Metode Penelitian Kualitatif: Sebuah Refleksi Artikel Hasil Penelitian.” Lingua:Jurnal Ilmu Bahasa Dan Sastra 10(1):18-23.

De Porter, B, \& Hernacki. M, . 2000. "Quantum Teaching (Terjemahan),.” In Bandung: Kaifa-Mizan.

Prasetyo, Y, A. (2018). 2018. "Pemanfaatan Media Pembelajaran Berbasis Teknologi Informasi Dan Komunikasi Dalam Pendidikan Pancasila Dan Kewarganegaraan Pada Smk Negeri 1 Selo." Laboratorium Ppkn Fkip Uns. 
4912 Teknologi Informasi dan Komunikasi sebagai Salah Satu Pemanfaatan Pembelajaran Pendidikan Kewarganegaraan di Sekolah Dasar - Defany Dwi Rahmadhani, Indah Cahaya Putri, Dinie Anggraeni, Yayang Furi Furnamasari

DOI : https://doi.org/10.31004/edukatif.v3i6.1574

Pratiwi, I, T, M., \& Meilani, R, I. 2018. "Peran Media Pembelajaran Dalam Meningkatkan Prestasi Belajar Siswa." Jurnal Kependidikan Manajemen Perkantoran 3(2):173-81.

Sejati, N, D, R, I. 2011. "Pemanfaatan Media Pembelajaran Pendidikan Kewarganegaraan Berbasis Teknologi Informasi Dan Komunikasi (Tik) Pada Smp Negeri 5 Semarang.” Universitas Negeri Semarang. 